DEPARTMENT OF THE INTERIOR UNITED STATES GEOLOGICAL SURVEY

PREPARED IN COOPERATION WITH THE NATIONAL SCIENCE FOUNDATION

SIMPLE BOUGUER GRAVITY MAP AND AEROMAGNETIC PROFILES OF THE THOMAS HILLS QUADRANGLE AND PART OF THE BLACKBURN NUNATAK QUADRANGLE, ANTARCTICA By

John C. Behrendt, William Rambo, John R. Henderson, and Laurent Meister

GEOPHYSICAL INVESTIGATIONS MAP GP-890

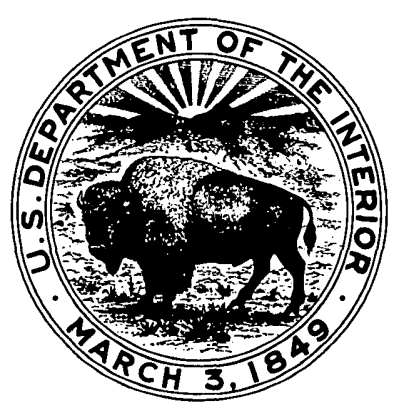




\title{
SIMPLE BOUGUER GRAVITY MAP AND AEROMAGNETIC PROFILES OF THE THOMAS HILLS QUADRANGLE AND PART OF THE BLACKBURN NUNATAK QUADRANGLE, ANTARCTICA
}

\author{
By John C. Behrendt, William Rambo, John R. Henderson, \\ and Laurent Meister ${ }^{1}$
}

\section{INTRODUCTION}

During the 1965-66 austral summer we made reconnaissance gravity and magnetic surveys of the Pensacola Mountains and the adjacent ice-covered area, Antarctica. The gravity survey consisted of 397 observations on ice or rock and seismic reflection measurements of ice thickness at 18 stations away from the mountains. Turbine helicopters were used and the work was coordinated with simultaneous geologic and topographic work by the U.S. Geological Survey. Reconnaissance aeromagnetic profiles were also flown perpendicular to the general northeast strike of the Pensacola Mountains. The objective of the geophysical surveys was to complement the geologic mapping in an effort to understand the tectonic development of the Pensacola Mountains and their relationship to the transition from West to East Antarctica. Behrendt and others (1966) discussed preliminary results of the geophysical work.

\section{GRAVITY SURVEY}

We used one Worden and two LaCoste and Romberg geodetic gravimeters. The Pensacola survey base station at Camp Neptune (Schmidt Hills quadrangle) was tied four times, over a period of several hours each, to the McMurdo base station (Behrendt and others, 1962). An additional check on the base station was a reoccupation of one of the 1957 IGY (International Geophysical Year) traverse stations on bedrock in the Dufek Massif (Behrendt, 1962). A difference of +0.9 mgal was observed when gravity at the base station was compared with that at the IGY traverse station; this difference is acceptable considering that the older data were all tied to North America by ship and land-surface vehicle (Behrendt and others, 1962) over a period of months and years. All gravity observations in this survey were tied to the Pensacola base station within a few hours and errors in observed gravity are negligible.

Absolute elevations are considered accurate within $\pm 25 \mathrm{~m}( \pm 5 \mathrm{mgal})$ and relative elevation within $\pm 10 \mathrm{~m}$ ( $\pm 2 \mathrm{mgal}$ ). Two seismic reflections from the waterice contact at the base of the Ronne Ice Shelf northwest of the Dufek Massif allowed a determination of sea level elevation based on hydrostatic equilibrium. Corrections were made for changes in seismic velocity resulting from density increase with depth in the upper ice shelf (Thiel and Behrendt, 1959) and absolute elevation accuracy was estimated conservatively, at the reflection stations, as $\pm 10 \mathrm{~m}$. The reflection stations were tied, one by vertical angle and one by altimetry, to the Pensacola Mountains control net. The elevations at stations in the survey were obtained from altimeter data corrected for temperature and for barometric pressure variations at a central control station. In addition, 97 gravity stations were at control points where vertical angle observations were made as part of the topographic mapping control. The standard deviation of the unadjusted altimetry data at the vertical angle stations is $\pm 12 \mathrm{~m}$. All altimeter elevations were adjusted by use of the 97 vertical angle stations as control.

Positions of gravity stations located at points in the topographic control net are accurate to tenths of seconds, and stations away from the mountains where graphic solutions of astronomical observations were made, are accurate to about one-tenth of a minute. Therefore, latitude-correction errors are negligible.

The largest source of error, and the most difficult to evaluate, is the terrain effect. Terrain corrections could not be made in the usual manner because of insufficient detail on the best maps $(1: 250,000$-scale, $200-\mathrm{m}$ contour interval) available. A large unknown effect due to subglacial terrain could not have been corrected for, even if larger scale maps had been available. The corrections could be as great as several tens of milligals in certain cases but experience suggests that they should be no more than $10 \mathrm{mgal}$ for most stations. We attempted to allow for terrain effects in contouring the maps by assuming that all corrections for stations on rock would be positive and that complete Bouguer anomaly (unknown) must be at least as positive as simple Bouguer anomaly.

\section{MAGNETIC SURVEY}

Total aeromagnetic intensity measurements were made along the flight paths indicated on the magnetic map using an Elsec Wisconsin proton precession magnetometer (Wold, 1964), flown in a LC-117 aircraft at a constant barometric elevation of $2,100 \mathrm{~m}$. Trimetrigon photography provided position control in the area of the mountains. Dead reckoning and solar observations, adjusted to the

\footnotetext{
'Geophysical Services International, London, England.
} 
photographically identified indicated points, were only control at the northwest and southeast ends of the flight paths over the featureless ice sheet. Consequently, position errors are variable but are minimal near the control points. Some paths crossed no identifiable rock outcrops and these have greater position errors. A reliable estimate of quantitative error is difficult to obtain but probably errors at the ends of the flight paths are several kilometers. Diurnal control was obtained from a base line connecting the profiles. No flights were made during magnetic storms.

Because of the widely spaced lines, position uncertainties, and relatively low amplitude and areal extent of the anomalies in this quadrangle, profiles rather than contours provide the most geologic information. Because the flight lines approximately parallel the main field contours, no regional gradient was removed.

\section{ACKNOWLEDGMENTS}

We thank D. L. Schmidt and W. H. Nelson, geologists, and M. A. Weber, topographic engineer, for making gravity observations at points visited in the course of their other work. R. E. Wanous assisted in the aeromagnetic survey. The topographic control party made the position and vertical angle elevation determinations. The U.S. Navy and U.S. Army provided logistic support. The National Science Foundation supported the research. C. R. Bentley of the University of Wisconsin Geophysical and Polar Research Center loaned the gravimeters, magnetometer, and seismic reflection equipment.

\section{REFERENCES}

Behrendt, J. C., 1962, Summary and discussion of the geophysical and glaciological work in the Filchner Ice Shelf area of Antarctica: Wisconsin Univ., Geophys. and Polar Research Center, Research Rept. 62-3, $66 \mathrm{p}$.

Behrendt, J. C., Meister, L. J., and Henderson, J. R., 1966, Airbone geophysical study in the Pensacola Mountains, Antarctica: Science, v. 153, no. 3742, p. 1373-1376.

Behrendt, J. C., Wold, R. J., and Laudon, T. S., 1962, Gravity base stations in Antarctica: Geophys. Jour., v. 6 , no. 3 , p. $400-405$.

Thiel, Edward, and Behrendt, J. C., 1959, Seismic studies on the Filchner Ice Shelf, Antarctica, in Thiel, Edward, Bentley, C. R., Ostenso, N. A., and Behrendt, J. C., Oversnow traverse programs, Byrd and Ellsworth stations, Antarctica, 1957-58: Am. Geog. Soc., Internat. Geophys. Year Glaciology Rept. Ser., No. 2, Group V, p. V1-V14.

Wold, R. J., 1964, The Elsec Wisconsin digital recording proton precession magnetometer system: Wisconsin Univ., Geophys. and Polar research Center, Research Rept. 64-4, 83 p. 